It is a little singular that certain species do not vary, species which are not only found from ocean to ocean in North A merica. but which are nearly or quite cosmopolitan. Why this should be true of some species and not of others is still an open question. If the scorching sun of the desert regions will bleach out one species why will it not do the same for another? The plea of adaptation of coloration for protection cannot be urged $b \in$ re.

Not only are colors affected, but size as well, by geographical position. This is probably more marked north and south than east and west. And yet the variation in size alone is not sufficient for a subspecific division. It is not at all strange that those individuals of a migratory species which push farthest north should possess stronger bones and muscles, and so be larger than those which were not able to fly so far. It would seem natural that the constant recurrence of such a difference would tend, in time, to form a race peculiar enough to be recognized as a sub species. But it has not proven true thus far in the history of the world, and why should there be any change under the same conditions?

Oberlin, Ohio, Dec. 26.

LYNDS JONES,

\section{On the Use of the Compound Eyes of Insects.}

IN an interesting note on the above subject by Mr. E. T. Lewis in Science of Dec. 2, there is a reference to my note on Professor Exner's beautiful researches on the question of how the compound eyes of insects see, in my recent edition of "The Microscope and Its Revelations." Mr. Lewis says (p. 315), "but it may be as well to note that the figure on page 908 of "The Microscope and Its Revelations' appears to have been laterally inverted by the engraver," his observations enabling him to say "that in the original photograph the letter $R$ was not reversed as shown in the wood-cut, and the church faced the other way."

This is entirely fallacious; the wood-cut in the current edition of the "Revelations of the Microscope" is in every sense correct. It has been seen by Exner, and was copied from the original photograph, which now lies before me as sent me by Professor Exner himself; and a study of "Die Physiologie der Facettirten Augen von Krebsen und Insecten" will make this clear.

Lee, London, S.E., England.

W. H. Dollinger.

\section{Discovery of Mexican Feather-Work in Madrid.}

THERE are not many well-preserved specimens of native Mexicae feather-work in existence, and every addition to their number is of interest and importance. During a recent visit to the land which gave birth to the conquerors of Mexico, Mrs. Zelia Nuttall - whose researches on Mexican antiquities are well knownwas so fortunate as to discover a fine example of Mexican feathermosaic in the shape of a valuable shield, with an authentic history, preserved in the Royal Armory of Madrid. It is known as the shield of Philip the Second, for whom it was indubitably made in Spain of cane and leather in the oval shape of the Moorish adarga. It was then sent out to Mexico with four beautiful Spanish designs of historical scenes and a central derice. These were executed in Mexico entirely of feather-mosaic, which covers the whole surface of the shield and makes it one of the most surprising and superb examples of this curious lost art of miniature painting with feathers. Mrs. Nuttall has paid considerable attention to the subject of ancient Mexican feather-work, and has already accumulated novel data which promise to throw light on the methods of its manufacture. We may look for an interesting paper on this subject from her pen before long.

Soon after the shield in question was identified by ber as of Mexican workmanship - an unrecognized fact which was not recorded in the oldest Inventories - it was removed from the Royal Armory and placed on exhibition in the interesting HispanoAmerican Historical Exposition in Madrid. In the Spanish section of the same building may now be found also the elaborate tables, fourteen metres long, originally dasigned to illustrate Mrs. Nuttall's "Preliminary Note on the Ancient Calendar of the Axtecs," which formed the most original and valuable communication presented to the recent Americanist Congress at Huelva. It was then generally admitted that Mrs. Nuttall had fairly solved the great problem which has long puzzled Mexicanist students in general. Guided by a luminous passage occurring in an unpublished Hispano-Mexican MS. which she had previously discovered in a Florentine library and intends to reproduce in fac-simile, Mrs Nuttall may be said to have furnished the key to the hitherto unknown calendar system of the ancient Aztecs. It now seems to be of a very simple and harmonious character and to have been employed by them, judging from astronomical calculations, for a period of at least 4,000 y ears.

The Mexican cycle, it appears from these researches, was one of 13,515 days. It comprised 52 ritual years, less five days at the end of the cycle, each year of 260 days, or 51 lunar years of 265 days, based on nine moons in each year, or 37 solar years of 365 dass in each year. At the end of the fifty-first lunar year ten intercalated days made the lunar year equal to the solar year, in such a manner that the new cycle began in the same lunar and solar positions as the preceding cy cle of 13,515 days. Each period began with a day bearing one of four names, acatl, tecpatl, calle', or tochtle'

This is the most important discovery hitherto made known by the indefatigable Nahuatl scholar. Full details will eventually be published in one of the Peabody Museum papers of the American Museum of Archæology, on which Mrs. Zelia Nuttall, special assistant in Mexican archæology, and director of the same department in the Columbian Exhibition, has already reflected much honor. AGNES CRANE.

Brighton, England, Dec. 20, 1892.

\section{Is it Instinct or Intelligence ?}

I HAVE a nearly pure-blooded water spaniel. Though a great pet and most valuable watch-dog, in my busy life I have devoted little time to trainıng him, - rather have watched carefully the development and application of his own powers, under a uniformly kind treatment. When only five weeks old, he made his first debut into the open world, - following mother and myself to church. Crossing the street, we heard the patter of little feet, and, looking around, I saw his nose close to the ground as the little ball trulged along. I took him home and started again, only to have the performance repeated, but this time I shut him in the house. Just as church service opened, mother thought she felt something strangely warm at her feet. And lo! there was Master Carlo. He had escaped, perseveringly follow ed our track around two blocks, and discovered mother in the congregation. From that time a remarkably keen scenc has been a prominent quality. Early he manifested a love for watching and chasing chickens, - a pastime not to be neglected with the small opportunities of the city. We soon. by kindnc ss and firmness and much talking, broke him of disturbing our own chickens. We often took a little chick in our hands, and said to him "pretty chickey, Carlo's chickey!" and allowed bi " to lick it gently. Soon it was not only safe, but safer to have him in the pen with the chicks than otherwise, as then no rat or mouse dared venture there. From the tirst, 'arlo has deemed these marauders worthy of death whenever and wherever seen. and acts out his convictions. As the chickens grew, and rhanksgiving approached, their number was reduced to twelie, and these were transferred to the barn. Every nioht 'or two years Carlo made a detour of the perches, giving each fowl a $0^{\circ}$ )d lick, - they were so acquainted it did not alarm them at all, - and if one or more of the number was absent, he would itumeliately scour the premives till it was found, then gave a $p+c u$ rark indicating the discovery; nor would be ive it un till he numher was complete. Could he count? How did he wow there should be just twelve-no more, no less? Occasionally a stray fowl would come to our yard. This he tommled by keeping it constantly "on the move." not by making if a a but simply kept it walking about, persistently, unles is 1 , th the street, when be considered it game, and pursued it thor u hly. The following spring and summer, as the chicks ba ' t" lay. he took it upon himself, without any teaching to find and bring in the eggs, never sucking any, and rat no ing them if broken, it was because he laid them dow " ly upon the veranda flour. When a 
hen stole her nest. he was sure to miss her and search her out, then get her eggs. if he could reach them; if unable to do so, he would stand and whine till aid came. In our daily drives. Carlo was accustomed to go with mother and me, so when left at home he was very sad. To deceive him as to our going, we came to spell the words go, barn and ride. For a few days the plan succeeded well, but, regardless of special tone or other (to us) apparent association, he soon pricked up his ears at the sound "g-o," and that mystery was solved, then followed "r-i-d-e" and "b a-r-n," till those combinations were nearly as significant of a pleasure-hour to him as to us.

During mother's long and severe illness, he took great interest in all that pertained to her, watching the doctor very closely, and sitting, by the half-hour, with his chin on the bed by her side. We bought our bread, and, knowing Carlo's fondness for warm biscuit, the baker often gave him one which he quickly despatched. Once, during a very severe attack of mother's, when we were doing our utmost to tempt her appetite, Carlo came in early one morning, bringing his warm biscuit untouched, and laid it on the floor by mother's side. Too sick to notice this act of his, but not to be disappointer in his own plan, he came forward and lifted the biscuit to her pillow, and retired again to his corner to wait some look of thanks from her. It came, and such a happy dog! He had brought his choicest offering - a warm biscuit - and it had been recognized. Was there a loring plan and careful observation in this act?

One day while busy writing, I heard him in the dining-room asking to go out. The outside doors were open, and I said "Yes, Carlo may go !" and returned to my desk. Soon he repeated his request, and I rose saying "Now you must go, and not bother me so !" but he lay quietly, though anxiously, in the middle of the floor. Going to him, I found he had my canary between his front feet, not a feather injured, but waiting for me to release it in safety. The cage had accidently been left open, and finding the bird free, with these outside doors of the room open, he had gently caught and beld my pet. Why should he catch it when the doors were open, when if closed he made no such effort? Who will say this was mere instinct? MARY E. HoLmes. Rockford, Ill.

\section{BOOK-REVIEWS.}

Deep-Sea Sounding. By CAPT. A. S. BARKER. U.S.N. New York, J. Wiley \& Sons, 1892.133 p. Maps. $8^{\circ}$.

CAPTAIN BARKER, in this rery interesting work, gives an account of the results of the explorations of deep-sea bottoms by the officers of the U.S.S. "Enterprise" in the years 1883-1886. The casts of the lead were made by Messrs. Norris and Marix, lieutenants attached to the "Enterprise," the one on the outward, the other on the homeward voyage. The ship sailed and steamed across the Atlantic and the Indian Oceans, and returned by way of the Pacific, sounding out different routes. Soundings were made daily, often for many days together; steam being raised for the purpose each time, and the fires allowed to go out again immediately after the cast. With characteristic naval spirit, the author assumes all responsibility for even the minutest detail, as where he says " $m y$ usual custom, during the cruise, was to use only two boilers when steaming," and where similar assumptions of credit in regard to details for which other officers were responsible, and which a commanding officer in the merchant service would have given credit for, and left absolutely, to the person best prepared by experience and judgment to perform. The two lieutenants who did the work, and the chief engineer, are, how ever, complimented as officers "whose intelligence, zeal, and devotion to duty could not be surpassed." This innocent and unconscious self assertion runs through the book.

The volume is very interesting, however, and contains much new and valuable information and data. New submarine mountain ranges were discovered, and previously unknown obstructions to navigation. The voyage terminated at the further side of the Indian Ocean, immediately after the great eruption of Krakatoa;

\section{CALENDAR OF SOCIETIES.}

Society of Natural History, Boston.

Jan. 4.-W. G. Farlow, Account of Some of the Botanical Establishments of Europe; J. Eliot Wolff, Application of the Microscope to the Study of Rocks.

\section{Entomological Society, Washington.}

Dec. 31. - The eighth annual and eightyfifth regular meeting of the society was held at the residence of the president, Dr. C. V. Riley. The following officers were elected: President, C. V. Riley; vice-presidents, W. H. Ashmead and C. W. Stiles; recording secretary, C. L. Marlatt; corresponding secretary, L. O. Howard ; treasurer, E. A. Schwarz; executive committee, the officers and Dr. W. H. Fox, Dr. Geo. Marx, and Mr. B. E. Fernow. Mr. Frank Benton was elected an active member. The retiring president, Dr. C. V. Riley, then delivered his annual address on the subject of "Parasitism in Insects." The address began with a definition of the term and a classification of the subject, and then treated in detail the following subdivisions: (1) The parasites among insects proper, by orders; (2) origin of insect parasitism; (3) effects of the parasitic life; (4) economic bearings of the subject. At the conclusion of the address, on motion of Dr. Gill, the thanks of the society were voted to the president.

Kindıy mention "Science" in writing to Advertisers.
TWO UNUSUALLY GOOD OFFERS REAL CHRISTMAS GIFTS.

First.-The great Holiday Number (enlarged to 2f, 6 pages) of that brightest of quarterly publications. "TALES FROM TOWN TOPICS," Out December 1 st, all news and book stands
and railway trains, price, 50 cts., will be sent FREE To all who send $\$ 1.00$ for 3 months' trial subscrip-
tion to

\section{TOWN TOPICS.}

The largest, raciest. strongest, most varied and entertaining weekly journal in the world SECOND. - To all who will send $\$ 5.00$, will be sent Town TOPICS and "TALES FROM TOWN TOPICS." from date until January 1, 1894, covering 5 numbers of the months of the greatest of family weeklies (rogular price $\$ 4.00$ per year).

Take one or the other offer AT ONCE and remit in postal notes, orders, or New York Ex-

roWn TOPICS, 21 West 23 d st., $\mathbf{Y}$. Fact and Theory Papers

I. THE SUPPRESSION OF CON SUMPTION. By GODFREY W. HAMBLETON, M.D. II. THE SOCIETY AND THE “FAD." By APPLETON MORGAN, Kisq. $12^{\circ}$. 20 cents.
III. PROTOPLASM AND LIFE. III. PROTOPLASM AND LIFE. By C. F. Cox. $12^{\circ}$. 75 cents.

IV. THE CHEROKEES IN PRE-CO LUMBIAN TIMES. BY CYRUS THOMAS. 120. $\$ 1$
V. THE TORNADO. By H. A. HAZEN

VI. TIME-RELATIONS OF MENTAL PHENOMENA. BY JOSEPH JASTROW. $12^{\circ}$. $50 \mathrm{c}$.
VII. HOUSEHOLD HYGIENE. By MARY HOUSEHOLD HYGIEN

N. D. C. HODGES, Publisher, 874 Broadway, New York.
Reading Matter Notices.

Ripans Tabules: best liver tonic. Ripans Tabules cure jaundice.

MINRAIS Cabinet Specimens, Collections, and MIIERALS, material by the pound, for mineralogists. collectors, colleges, schools, and chemists. cloth bound, 25 cents; supplement 2 cents. GEO. L. ENGLISH \& Co., Mineralogists, 723 \& 735 B'way, N. Y. ACK NUMBERS and complete sets of leading Mag-
azines. Rates low. AM. MAG. EXCHANGE,
Schoharie N V

\section{RESTORE YOUR EYESIGHT} Cataracts, scars or films can be absorbed and
paralyzed nerves restored, without the knife or risk. Diseased eyes or lids can be cured by dreds convinced. Our Ilustrated pamphlet Everybody wants it. “ TEE EYE," Glens Falls, N.Y.

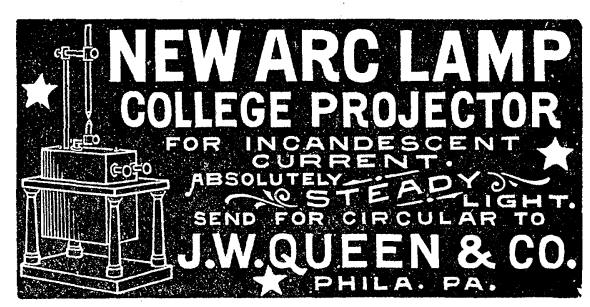

FOR SALE

Audubon's "Birds of America," 7 vols.; Audubon's "Quadrupeds of America," 3 vols.; McKenney's “Indian Tribes of AmerIca," 3 vols. Price, $\$ 200$. Address

C. A. MOUTON, Lafayette, La. 